\title{
高密度指向性表示による 自然な立体表示
}

O立体ディスプレイ, 自然な立体表示, 高密度指向性表示, ヒューマンファクタ

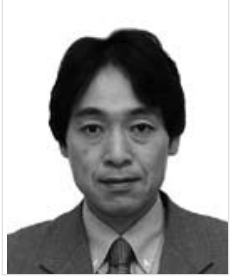

高木 康博

\section{1.はじめに}

従来の立体ディスプレイには，人間の立体視機能に対し て二つの矛盾がある。第一の矛盾は, 輻輳と調節の不一致 であり，眼精疲労を引き起こすと言われている。第二の矛 盾は，運動視差の欠如や不完全さで，臨場感を低下させる と言われている。立体デイスプレイが幅広く普及するため には，これらの矛盾がない自然な立体ディスプレイの実現 が必要である。

本稿では，自然な立体表示を実現する高密度指向性表 示 $^{(1)}{ }^{(2)}$ (High-Density Directional 表示, 以下, HDD 表示 と略す)，これを実現する HDD ディスプレイ ${ }^{(1) \sim(7) ， お よ ~}$

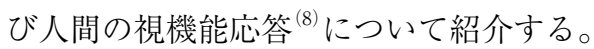

\section{2. 高密度指向性表示}

輻輳と調節の不一致は，眼の焦点合わせ機能である調節 が立体像に対してではなく，画像を表示しているディスプ レイスクリーンに合い, 調節が正しく機能しないために生 じる。このような不一致は, 日常生活では起こらないた め，眼精疲労を引き起こすと言われている。

従来の多眼表示では, 空間に複数の視点を設定し, これ らの視点を通して見える一点透視投影画像 (視差画像) を 対応する視点位置に表示する。すなわち, 視点位置に関し てサンプリングを行う。これに対して，HDD 表示(1)(2) で は, 画像を表示する光線を, 進行方向に関してサンプリン グする。図 1 に示すように，表示物体を平行投影（正射 影）した指向性画像を投影方向を微妙に変えて多数用意す る。これを対応する方向へ準平行光（指向性光線）で表示 する。図 1 では, 説明のために指向性画像が 5 枚の場合を

たかき・やすひろ 1992 年早稲田大学大学院理工学研究科 博士後期課程修了 (博士 (工学) 取得)。1991 年同大学助手。 1994 年日本大学文理学部専任講師。1998 年同助教授。2000 年 東京農工大学工学部助教授。立体ディスプレイ技術, ホログラ フィに関する研究に従事。
示している。光線のサンプリング角度ピッチを狭めて指向 性を高めると，図 1 に示すようにスクリーンから発せられ 物体の一点を通る光線が 2 本以上同時に曈に入射するよう になり，眼はこの点に対してピント合わせできるようにな り，調節が正しく機能する可能性がある。

HDD 表示を実現するために必要な光線の表示角度ピッ チは, 眼の瞳孔径と観察距離に依存する。瞳孔径は平均で $5 \mathrm{~mm}$ で，輻輳と調節の不一致が問題になる観察距離は約 $1 \sim 2 \mathrm{~m}$ 以内であることから，必要な表示角度ピッチは 0.1 〜 $0.3^{\circ}$ と非常に小さくなる。両眼で立体像を観察する ためには，視域角は $20^{\circ}$ 以上は必要であるから，表示する 画像数は約 $70 \sim 140$ 以上と非常に多くなる。

このように HDD 表示では，光線のサンプリング角度ピ ッチを非常に小さくし，物体から発せられる光線を詳細に 再現するため，滑らかな運動視差が得られる。

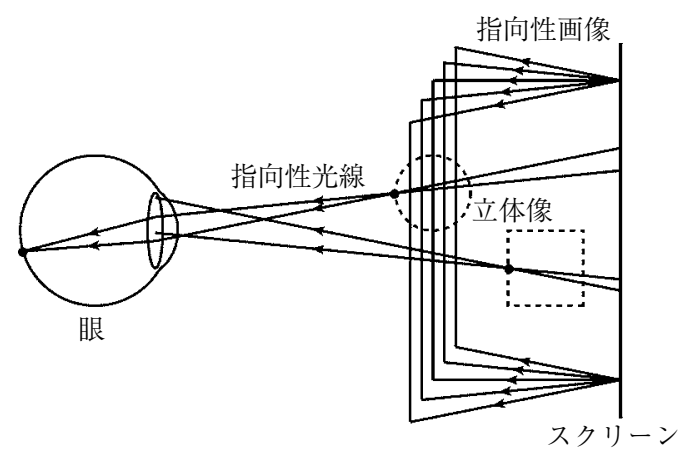

図 1 高密度指向性表示

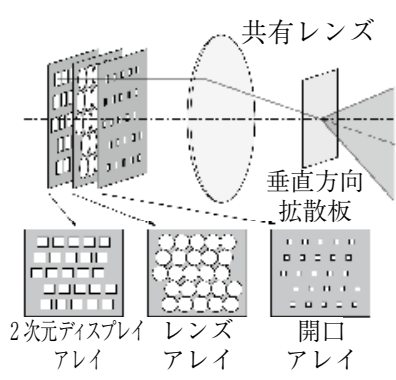

(a) プロジェクション型

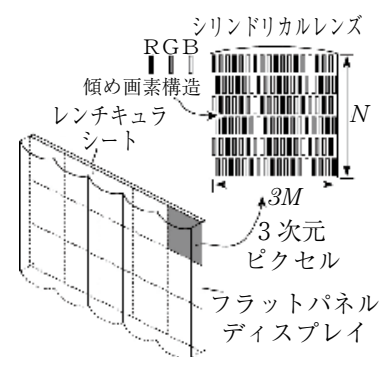

(b) フラットパネル型
図 2 高密度指向性ディスプレイ 
表 1 高密度指向性ディスプレイ

\begin{tabular}{|c|c|c|c|c|c|c|}
\hline 指向性数 & $64^{(1)(2)}$ & $128^{(3)}$ & $128^{(4)}$ & $72^{(5)}$ & $72^{(6)}$ & $30^{(7)}$ \\
\hline システム & プロジェクション & プロジェクション & プロジェクション & フラットパネル & フラットパネル & フラットパネル \\
\hline 水平表示角度ピッチ & $0.34^{\circ}$ & $0.23^{\circ}$ & $0.28^{\circ}$ & $0.38^{\circ}$ & $0.38^{\circ}$ & $0.71^{\circ}$ \\
\hline 水平視域角 & $21.6^{\circ}$ & $29.6^{\circ}$ & $35.7^{\circ}$ & $27.6^{\circ}$ & $27.6^{\circ}$ & $21.2^{\circ}$ \\
\hline 解像度 & $\sim$ QVGA & $\sim$ QVGA & $800 \times 600$ & $320 \times 400$ & $640 \times 400$ & $256 \times 128$ \\
\hline スクリーンサイズ & $9.25^{\prime}$, & $13.2^{\prime \prime}$ & $12.8^{\prime \prime}$ & $22.2^{\prime \prime}$ & $22.2^{\prime \prime}$ & 7.2, \\
\hline 外 観 & & & & & & \\
\hline & 1 & & & & & \\
\hline
\end{tabular}

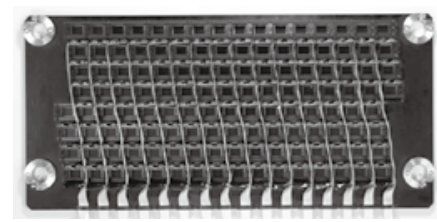

(a) LCD アレイ

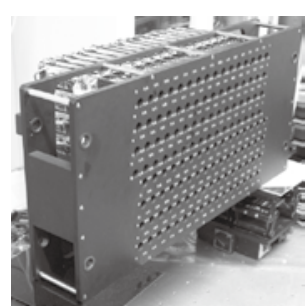

(b) プロジェクタアレイ

図 3 プロジェクション型での変形二次元配置
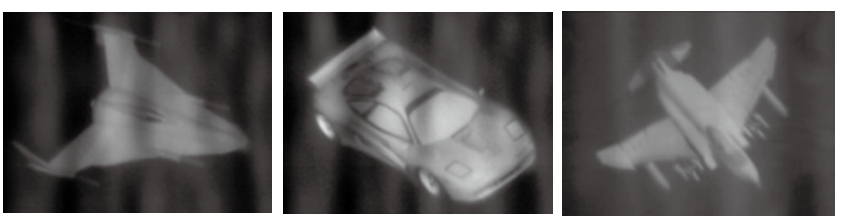

図 4128 指向性 SVGA ディスプレイの立体像

\section{3. 高密度指向性ディスプレイ}

HDD ディスプレイの構成方法には，図 2 に示すよう に，(a)プロジェクション型と（b) フラットパネル型の 2 種類がある。プロジェクション型では, 多数のプロジェク 夕を水平位置が一致しないように上下に水平位置をずらし て変形二次元配置する。このような配置を用いると, すべ ての画像が異なる水平方向へ表示される。フラットパネル 型 ${ }^{(9)}$ では，レンチキュラシート背面に配置されるフラット パネルデイスプレイの色画素の配列を水平位置が一致しな いように上下に水平位置をずらして変形二次元配置する。 このような構成を用いると, 異なる色画素から出射される 光線はレンズですべて異なる水平方向へ偏向される。

筆者らは，現在までに 6 種類の HDD ディスプレイ ${ }^{(1) \sim(7)}$ を試作している。これらを表 1 に示す。

プロジェクション型では，最初に実証システムとして 64 枚の画像を表示する 64 指向性ディスプレイ ${ }^{(1)(2)}$ を試作 し，その後，光線の指向性を高め指向性数を増やした 128 指向性ディスプレイ ${ }^{(3)}$ を試作した。これに用いた変形二次
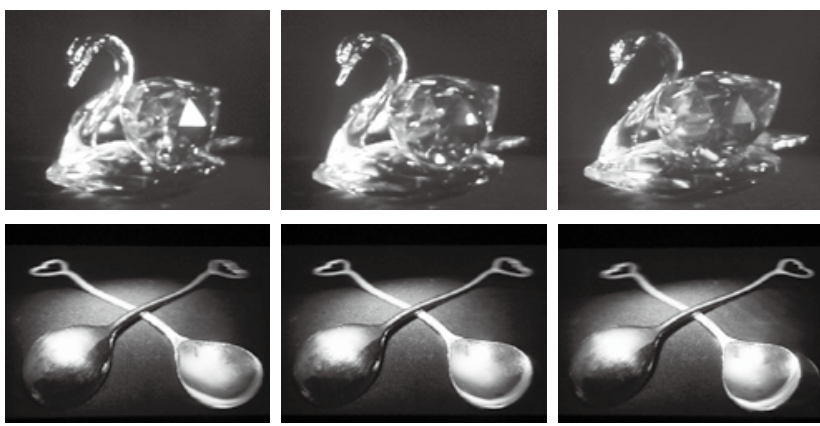

図 572 指向性 VGA ディスプレイの立体像

元配置した 128 個の LCDを図3(a) に示す。さらに，解 像度を SVGA に向上させたシステム ${ }^{(4)} も$ 試作している。 これに用いた変形二次元配置した 128 個の小型プロジェク 夕を図 3(b) に示す。128指向性 SVGA ディスプレイの立 体像を図 4 に示す。

フラットパネル型では，変形二次元配置した画素配列を 有するフラットパネルディスプレイが存在しないため，実 際にはレンチキュラシートの方を傾けた斜めレンチキュラ 方式を用いた。最初に 72 指向性ディスプレイ ${ }^{(5)}$ を試作し， 次に，これを 2 台組合せて解像度をVGA 相当 $(640 \times$ 400）に向上させたディスプレイ ${ }^{(6)}$ を試作した。なお，30 指向性ディスプレイ ${ }^{(7)}$ はモバイル用に(株) NTTドコモと 共同で開発したもので，モバイル用では観察距離が短いこ とから光線の指向性は 0.71 と大きくしてある。72 指向性 VGA ディスプレイの立体像を図 5 に示す。これらは異な る水平方向から撮影した写真である。

\section{4. 高密度指向性表示による被写界深度の拡大}

試作した HDD ディスプレイに対する調節応答の測定 例 ${ }^{(8)}$ を図 6 に示す。指標（立体像）までの距離と調節応答 は，眼からピント位置までの距離 $[\mathrm{m}]$ の逆数である Diopter [D] で示している。○プロットは立体像にぼけ が感じられなかった場合，○プロットはぼを感じた場

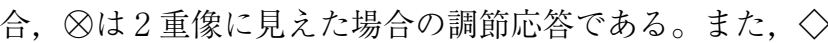




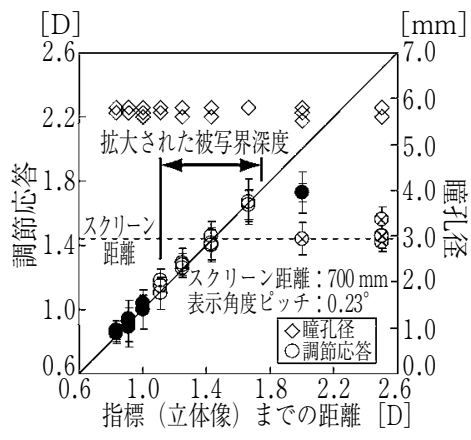

(a)

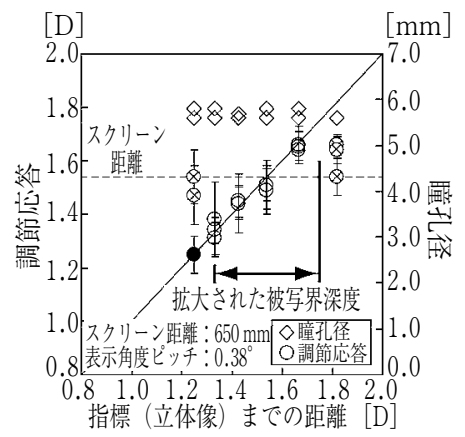

(b)
図 6 高密度指向性表示に対する調節応答：(a) 128 指向性デ ィスプレイ，（b）72 指向性ディスプレイに対する結果

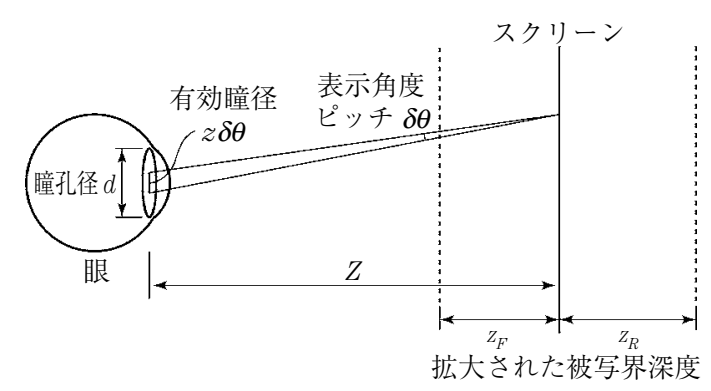

図 7 高密度指向性表示による被写界深度の拡大

プロットは睲孔径を示している。○プロットの位置でほぼ 正しい調節応答が得られているが, この範囲はディスプレ イスクリーン前後に存在している。実は, この結果は, 空 間の一点を通る光線が 2 本以上同時に瞳に入射すると調節 が機能するという考え方ではうまく説明できない。光線の 表示角度ピッチが一定であるので, 立体像の表示位置を眼 に近づけると, 空間の一点を通る光線が 2 本以上同時に瞳 に入射するようになるからである。

以上のようにスクリーンを中心として調節が正しく機能 する範囲が存在することは, 眼球結像系の被写界深度を考 えることで説明できる。通常の結像系では, 被写界深度は 結像系の瞳の大きさで決まる。従来の立体表示では, 眼の 瞳が眼球結像系の瞳となる。しかし, HDD 表示では, 図 7 に示すように, 瞳での光線の広がり $z \delta \theta$ が小さいため, この光線の広がりが眼球結像系の実質的な瞳の大きさを与 える。結像系の瞳が小さくなると被写界深度が拡がるが,
被写界深度を与える理論式に瞳の大きさとして, 光線 の広がりを用いて計算した拡大された被写界深度の範 囲を図 6 に示してあるが，○プロットの存在範囲とよ く一致していることが分かる。

以上のことから, HDD 表示では, 眼球結像系の被 写界深度が拡大し, その範囲内に表示した立体像に対 して調節が機能すると説明できる。

\section{5.おわりに}

輻輳と調節の不一致がなく滑らかな運動視差を有す る自然な立体表示方式として HDD 表示について説明 し，試作した HDD ディスプレイを紹介した。また， HDD 表示に対する人間の調節応答の測定結果を示し, HDD 表示は眼の被写界深度を拡大する効果を有すること を示した。

(平成 19 年 7 月 2 日受付)

（1）高木康博：「変形 2 次元配置した多重テレセントリック光学系を 用いた 3 次元デイスプレイ」, 映情学誌, 57, 2, pp.293-300（2003）

(2) Y. Takaki : "High-density directional display for generating natural three-dimensional images," proc. of the IEEE, Vol. 93, No. 3, pp.654-663 (2006)

( 3 ) H. Nakanuma, H. Kamei, and Y. Takaki : "Natural 3D display with 128 directional images used for human-engineering evaluation," Stereoscopic Displays and Virtual Reality Systems XII, Proc. SPIE, 5664, 28-35, San Jose, California (2005)

(4) K. Kikuta and Y. Takaki : "Development of SVGA resolution 128-directional display", Stereoscopic Displays and Virtual Reality Systems XIV, Proc. SPIE, 6490, U1-8, San Jose, California (2007)

(5) Y. Takaki : "Thin-type natural three-dimensional dispay with 72 directional images," Stereoscopic Displays and Virtual Reality Systems XII, Proc. SPIE, 5664, pp.56-63, San Jose, California (2005)

(6) Y. Takaki and T. Dairiki : "72-directional display having VGA resolution for high-appearance image generation," Stereoscopic Displays and Virtual Reality Systems XIII, Proc. SPIE, 6055, 0X-1-8, San Jose, California (2006)

( 7 ) M. Tsuboi, M. Fujioka, Y. Takaki, and T. Horikoshi : "Real time rendering for a full parallax 3D display using high-density directional images," the 13th International Display Workshops (IDW' 06), pp.1379-1380, Otsu, Japan (2006)

(8) Y. Takaki and H. Kikuta: "3D images with enhanced DOF produced by 128 -directional dispay," the 13th International Display Workshops (IDW' 06), pp.1909-1912, Otsu, Japan (2006)

(9) 高木康博:「レンチキュラー方式に用いる二次元ディスプレイの 画素構造に関する考察」, 3 次元画像コンファレンス 2006 論文集, pp.57-60 (2006) 